\title{
JUDUL 4 \\ PELAKSANAAN SISTEM MANAJEMEN KESELAMATAN DAN KESEHATAN KERJA (K3) PADA PROYEK KONSTRUKSI BANGUNAN (Studi kasus pada Proyek Kota kasablanka)
}

Dina Widya Astuti, Drs. Y.P. Panjaitan, S.H., R.Eka Murtinugraha, M.Pd.

\section{PENDAHULUAN}

Pemerintah yang diwakili oleh Departemen Tenaga Kerja dan Transmigrasi (Depnakertrans) telah menetapkan sebuah peraturan perundangan yang tertuang dalam Peraturan Menteri Tenaga Kerja (Permenaker) Nomor : PER.05/MEN/1996 tentang sistem manajemen K3 yang diharapkan dapat menjadi acuan bagi setiap perusahaan yang ada di Indonesia untuk melaksanakan sistem manajemen K3 pada perusahaan. Namun pada umumnya perusahaan melaksanakan sistem manajemen K3 belum sepenuhnya mencakupi semua ketentuan yang ada dalam peraturan tersebut. Pada umumnya perusahaan melaksanakan manajemen K3 dikondisikan dan disesuaikan dengan kemampuan perusahaan itu sendiri.

Hal itu diperkuat dengan data dari International Labour Organization (ILO) yang menilai bahwa pelaksanaan sistem manajemen K3 di Indonesia kurang memuaskan. Dipaparkan bahwa dari 15.043 perusahaan skala besar, hanya sekitar 317 perusahaan $(2,1 \%)$ yang menerapkan Sistem Manajemen K3. Itu berarti meskipun Indonesia telah menerapkannya, tetapi masih perlu terus meningkatkan pelaksanaan sistem manajemen K3.

PT. Acset Indonusa merupakan salah satu perusahaan konstruksi yang saat ini sedang memegang peran penting sebagai kontraktor utama di sebuah proyek konstruksi bangunan di DKI Jakarta yaitu pada proyek Kota Kasablanka. Proyek ini termasuk proyek berskala besar dan memiliki peluang yang cukup besar pula akan terjadinya kecelakaan kerja, maka perusahaan menerapkan sistem manajemen K3 yang dilaksanakan oleh Healthy, Safety and Environment Departement (HSE Dept) untuk mencegah terjadinya kecelakaan kerja pada proyek yang dapat menghambat produktifitas kerja pada proyek. Berdasarkan hasil wawancara singkat dengan HSE manager pada proyek ini, diketahui bahwa masih terdapatnya angka kecelakaan kerja dan belum pernah mencapai angka kecelakaan kerja nihil (zero accident). Selain itu, pelaksanaan sistem 
manajemen K3 pada proyek ini disesuaikan dengan kemampuan perusahaan. Walaupun demikian, pelaksanaan sistem manajemen pada proyek tersebut tetap mengacu kepada peraturan-peraturan yang ada, namun belum sepenuhnya mengacu kepada Permenaker No : PER.05/MEN/1996 yang telah disebutkan sebelumnya mengenai kewajiban menerapkan sistem manajemen $\mathrm{K} 3$.

masalah yang akan diteliti dibatasi hanya pada masalah mengenai pelaksanaan sistem manajemen K3 pada proyek konstruksi bangunan dalam hal ini pada proyek Kota Kasablanka secara umum dengan batasan pada perencanaan, pelaksanaan, pengecekan dan pengontrolan bagi pekerja serta tindakan pencegahan bahaya kecelakaan kerja dan penanganan yang dilakukan jika terjadi kecelakaan kerja.

\section{Manajemen.}

George R. Terry mendefinisikan manajemen sebagai suatu proses khas yang terdiri dari tindakan-tindakan perencanaan,pengorganisasian,penggerakan dan pengendalian yang dilakukan untuk menentukan serta mencapai sasaran yang telah ditentukan melalui pemanfaatan sumber daya manusia dan sumber daya lainnya.

Fungsi manajemen : perencanaan,pelaksanaan,pengorganisasian dan pengendalian.

\section{Kecelakaan kerja.}

menurut Suma'mur (1981), kecelakaan kerja (accident) adalah suatu kejadian atau peristiwa yang tidak di inginkan yang merugikan terhadap manusia, merusakkan harta benda atau kerugian proses digunakan untuk konstruksi dinding bangunan yang yang dibuat dari tanah liat dengan atau tanpa dicampur bahan aditif dan dibakar pada suhu tertentu.

Teori kecelakaan kerja :

a. Teori Heinrich kondisi yang tidak aman dan tindakan yang tidak aman

b. Teori Frank E Bird Peterson

kecelakaan terjadi karena adanya kontak dengan suatu sumber energi seperti mekanis, kimia, kinetik dan fisis yang dapat mengakibatkan cedera pada manusia, alat maupun lingkungan.

c. Teori Gordon 
penyebab terjadinya kecelakaan, harus diketahui karakteristik dari korban kecelakaan, perantara dan lingkungan secara detail.

d. Teori Faktor Manusia (Human Factor Theory) kecelakaan terjadi karena bahwa pada akhirnya semua kecelakaan kerja, baik secara langsung maupun tidak langsung disebabkan oleh kesalahan manusia.

e. Teori Domino Terbaru

Dalam teori tersebut diungkapkan bahwa penyebab terjadinya kecelakaan adalah adanya ketimpangan manajemen.

\section{Keselamatan dan Kesehatan Kerja (K3)}

Sedangkan menurut Suma'mur (2001, p.104), keselamatan kerja merupakan rangkaian usaha untuk menciptakan suasana kerja yang aman dan tentram bagi para karyawan yang bekerja di perusahaan yang bersangkutan.

\section{Sistem Manajemen K3.}

Sistem Manajemen Keselamatan dan Kesehatan Kerja yang selanjutnya disebut Sistem Manajemen K3 adalah bagian dari sistem manajemen secara keseluruhan yang meliputi struktur organisasi, perencanaan, tanggung jawab, pelaksanaan, prosedur, proses dan sumber daya yang dibutuhkan bagi pengembangan, penerapan, pencapaian, pengkajian dan pemeliharaan kebijakan K3 dalam rangka pengendalian resiko yang berkaitan dengan kegiatan kerja guna terciptanya tempat kerja yang aman, efisien dan produktif (Permenaker Nomor : PER.05/MEN/1996) tentang sistem manajemen K3

\section{Proyek Konstruksi Bangunan.}

Menurut Istimawan (1996), proyek merupakan upaya kegiatan yang diorganisasikan untuk mencapai tujuan, sasaran, dan harapan-harapan penting dengan menggunakan anggaran dana serta sumber daya yang tersedia, yang harus diselesaikan dalam jangka waktu tertentu. 


\section{METODA}

Tujuan dari penelitian ini adalah untuk mengetahui gambaran pelaksanaan sistem manajemen Keselamatan dan Kesehatan Kerja (K3) secara umum pada Proyek Kota Kasablanka.

Penelitian ini dilakukan di proyek Kota Kasablanka area Kota Kasablanka (KK) 2 dengan P.T Acset Indonusa sebagai kontraktor utamanya. Waktu penelitian dilaksanakan pada bulan Desember 2011 hingga selesai.

Penelitian ini merupakan penelitian deskriptif dengan pendekatan survey. Penelitian deskriptif merupakan penelitian yang dimaksudkan untuk mengumpulkan informasi mengenai status suatu gejala yang ada, yaitu keadaan gejala menurut apa adanya pada saat penelitian dilakukan (Arikunto, 2005). Metode penelitian yang digunakan dalam penelitian ini adalah metode survey. Populasi dalam penelitian ini adalah seluruh pekerja pada tingkat labour pada Proyek Kota Kasablanka dengan jumlah 513 pekerja. Namun untuk mendukung hasil penelitian tentang pelaksanaan sistem manajemen K3 pada proyek ini, penulis juga akan mewawancarai petugas K3 pada proyek ini yaitu dengan populasi sebanyak 18 orang.

Teknik pengumpulan data yang digunakan peneliti adalah dengan menggunakan angket/kuisioner untuk responden utama yaitu para pekerja di tingkat labour mengenai sistem manajemen K3 di lapangan yang telah dipaparkan sebelumnya dan menggunakan wawancara terstruktur untuk responden pendukung yaitu personel safety mengenai sistem manajemen K3 berdasarkan peraturan. Peneliti juga akan melakukan pengamatan secara langsung di lapangan untuk membuktikan bahwa jawaban kuisioner dari sampel penelitian sesuai dengan keadaan di lapangan disertai dengan dokumentasi.

Bentuk angket/kuisioner yang disusun menggunakan Skala Guttman. Dalam skala Guttman, variabel yang akan diukur dijabarkan menjadi indikator variabel. Kemudian indikator tersebut dijadikan sebagai titik tolak untuk menyusun item-item instrumen yang dapat berupa pertanyaan atau pernyataan. Skala Guttman yang digunakan dalam penelitian ini menggunakan dua alternatif jawaban yaitu Ya atau Tidak (Sugiyono 2007).

\section{HASIL DAN PEMBAHASAN}




\section{Pengolahan Data}

Data yang diperoleh dalam penelitian ini menggunakan instrumen peneltian berupa angket/kuisioner. Jenis kuisioner yang digunakan yaitu kuisioner tertutup dimana pada angket tertutup jawabannya sudah tersedia dan sampel penelitian yaitu para pekerja di proyek Kota Kasablanka dalam tingkat labour yang telah dipilih secara acak sebelumnya tinggal memilih jawab yang sesuai.

Hasil jawaban dari sampel penelitian melalui penyebaran kuisioner tersebut kemudian diolah dan disajikan dalam bentuk persentase. Persentase tersebut menggambarkan keseragaman jawaban sampel penelitian serta menunjukkan seberapa jauh sumbangan tiap-tiap bagian (aspek) di dalam keseluruhan konteks permasalahan dalam penelitian ini.

\section{Hasil Penelitian}

Dari hasil perhitungan rencana anggaran biaya untuk 21 rumah sederhana, didapat nilai persentase penerapan sistem manajemen K3 pada tiap indikator sebagai berikut :

- indikator perencanaan adalah sebesar $70,97 \%$

- untuk indikator pelaksanaan sebesar $67,41 \%$,

- pengorganisasian $81,15 \%$ dan

- pengontrolan sebesar $60,87 \%$.

\section{Pembahasan Hasil Penelitian}

1. Perencanaan

Untuk mencapai tujuan dari sebuah badan usaha maupun organisasi dalam hal ini adalah HSE Dept., diperlukan adanya perencanaan yang matang dan terarah. Dalam hal ini, hal-hal yang termasuk ke dalam perencanaan pada sistem manajemen K3 mencakup kebijakan dan pengenalan K3 itu sendiri kepada seluruh pihak yang terlibat di lapangan. Berdasarkan jawaban dari sampel penelitian didapatkan bahwa komitmen perusahaan dalam melaksanakan kebijakankebijakan K3 yang disusun sebelumnya dalam perencanaan masih kurang. Hal tersebut pun dibenarkan oleh pihak manajemen. Keterbatasannya petugas-petugas K3 yang ahli di bidangnya 
menjadi kendala bagi pihak manajemen K3 untuk merealisasikan semua perencanaan yang dibuat.

\section{Pelaksanaan}

Seperti dalam uraian sebelumnya, bahwa pelaksanaan sistem manajemen K3 pada penelitian ini didasarkan atas susunan perencanaan. Pelaksanaan ini dilakukan untuk mencapai sasaran K3 yaitu mencegah terjadinya kecelakaan kerja dan menuju angka kecelakaan nihil (zero accident). Namun kenyataannya di lapangan pencapaian menuju angka tersebut cenderung nihil. Masih banyaknya kecelakaan kerja yang terjadi berdasarkan data kecelakaan kerja yang ada akibat kurangnya kesadaran para pekerja dalam penggunaan APD sewaktu bekerja. Hasil kuisioner pun membuktikan bahwa pelaksanaan sistem manajemen K3 di lapangan dirasakan masih kurang berdasarkan rata-rata persentase jawaban responden atas sub-sub indikator pelaksanaan yaitu pelatihan, SOP, APD, pencegahan kecelakaan kerja, kegiatan dan prasarana K3 kurang dari $70 \%$, yaitu sebesar $66,6 \%$ rata-rata yang didapat dengan pelaksanaan tertinggi yaitu pada kegiatan K3 yang didalamnya berupa pengarahan sebesar $77,65 \%$. Sedangkan pelaksanaan yang paling rendah yaitu mengenai pelaksanaan pelatihan bagi tenaga kerja dimana rata-rata jawaban yang diperoleh hanya 49,43\%. Hal tersebut didukung dari hasil wawancara memang belum pernah diadakannya pelatihan bagi tenaga kerja dan hal ini menjadi salah satu bukti bahwa pelaksanaan sistem manajemen K3 pada proyek ini belum sepenuhnya sesuai dengan PER.05/MEN/1996 yang mana didalamnya terdapat poin yang menyebutkan bahwa diadakannya pelatihan K3 bagi seluruh tenaga kerja.

\section{Pengorganisasian}

Pengorganisasian yang baik akan menghasilkan kinerja yang baik pula. Pengorganisasian manajemen K3 disusun pada sebuah struktur organisasi. Pada umumnya, pengorganisasian pada HSE Dept proyek area KK 2 sudah berjalan dengan baik.terbukti dengan adanya koordinasi yang baik antara supervisor yang melakukan monitoring di lapangan dengan manajer K3 di office setiap harinya. Namun sesungguhnya Acset tidak bekerja sendiri. Masih adanya perusahaanperusahaan lain dalam hal ini Sub Cont yang mempekerjakan para pekerjanya di lapangan. Berdasarkan wawancara yang peneliti lakukan diketahui bahwa mengenai kerja sama dengan para supervisor lain ataupun dengan mandor masih kurang. Terbukti ditemukannya pelanggaran 
K3 yang dilakukan para pekerja di lapangan dengan diketahui oleh mandor (dalam dokumentasi lampiran 25), tetapi tidak ada peneguran yang dilakukan sehingga petugas K3 yang harus turun tangan. Sedangkan berdasarkan hasil jawaban responden kesiapan petugas K3 dalam menghadapi keadaan darurat masih kurang. Hal tersebut dikarenakan tidak adanya sistem penandaan bahaya yang mana seharusnya terdapat pada proyek sebagaimana yang tercantum dalam PER.05/MEN/1996.

\section{Pengontrolan}

Untuk menjamin dan mengukur apakah pelaksanaan sistem manajemen K3 yang disusun sebelumnya telah dilaksanakan organisasi atau belum serta untuk mengetahui apakah pelaksanaan tersebut berjalan dengan baik dan efisien atau tidak, diperlukan adanya pengontrolan di lapangan. Dalam hal ini pengontrolan terbagi atas pengawasan, pemeriksaan dan pemantauan. Pengontrolan dari dalam yang dilaksanakan oleh petugas K3 dirasakan masih rendah terutama mengenai pemantauan kesehatan kerja yang sampai saat ini belum pernah dilaksanakan. Tidak adanya pengawasan dari luar pun menjadikan pemicu akan kekurangsesuaian praktek sistem manajemen K3 pada proyek Kota Kasablanka. Tingginya angka kecelakaan yang disebabkan oleh unsafe action pekerja mengindikasikan bahwa pengawasan terhadap pekerja di lapangan tergolong kurang.

Pada umumnya gejala-gejala yang timbul sebagai penyebab kecelakaan maupun insiden kerja yang terjadi merupakan gejala dari pelaksanaan sistem manajemen sebagai akarnya. Salah satu contoh yaitu berdasarkan peristiwa kecelakaan kerja yang terdapat pada lampiran 29 menunjukkan bahwa kurangnya pengawasan manajemen atas alat bantu kerja di lapangan yang kurang layak digunakan menyebabkan terjadinya kecelakaan kerja tersebut. Andai saja, pihak manajemen telah memastikan sebelumnya bahwa alat bantu kerja di lapangan telah aman digunakan, maka peristiwa tersebut dapat dicegah. Hal tersebut membuktikan bahwa teori yang diungkapkan oleh Bennet N.B dan Rumondang Silalahi bahwa manajemen adalah akar dari kecelakaan kerja yang terjadi terbukti benar. Sedangkan dalam teori Heinrich's domino, pembuktian dalam kasus tesebut yaitu apabila manajemen K3 mengambil tindakan sebelumnya dengan memastikan alat bantu kerja di lapangan dalam kondisi aman dan layak pakai, maka jatuhnya "pion" pertama dapat dicegah. 


\section{KESIMPULAN}

1. Hasil penelitian ini menunjukkan bahwa pelaksanaan Sistem Manajemen K3 pada proyek Kota Kasablanka dengan PT. Acset Indonusa sebagai kontraktor utamanya belum mencakupi hal-hal yang sebagaimana telah diatur dalam Peraturan Menteri Nomor : PER.05/MEN/1996 dilihat dari belum terlaksananya prosedur-prosedur yang dibuat perusahaan di lapangan dan tidak adanya pelatihan dan pemantauan standar bagi tenaga kerja. Petugas K3 pun hanya mendapatkan pelatihan penggunaan APAR yang dilakukan oleh pengurus.

2. Kurangnya pemenuhan pelaksanaan Sistem Manajemen K3 pada Proyek Kota Kasablanka, khususnya pada area KK2 berdasarkan hasil wawancara dikarenakan beberapa faktor, antara lain yaitu kurangnya kemampuan dan pengetahuan yang dimiliki oleh petugas K3 mengenai sistem manajemen K3, kurangnya kerja sama yang baik dengan supervisor lain yang umumnya hanya mengandalkan tim K3 dari Acset, serta tidak adanya pengawasan dari badan pemerintah yaitu Depnakertrans, sehingga kemajuan dalam pelaksanaan sistem manajemen K3 pada proyek ini masih kurang.

3. Pekerja pada tingkat labour memiliki kesadaran yang minim untuk mentaati peraturan $\mathrm{K} 3$ yang telah ditetapkan terutama mengenai penggunaan Alat Pelindung Diri (APD). Terbukti dari rata-rata jawaban sampel penelitian yaitu hanya sebesar 60,5\% untuk kedisiplinan penggunaan APD, didukung data statistik kecelakaan kerja dimana tindakan yang tidak aman (unsafe action) menjadi penyebab utama terbesar dalam kecelakaan kerja yang terjadi pada proyek Kota Kasablanka.

4. Pada umumnya kebijakan, fasilitas atau prasarana K3 sudah dilaksanakan dan disediakan oleh pihak manajemen K3, namun ketersediaannya dirasakan masih kurang bagi para pekerja. Dalam hal ini seperti ketersediaan APD dan fasilitas kesehatan kerja.

5. Pengetahuan dan kemampuan pekerja dalam melakukan suatu proses pekerjaan masih kurang memenuhi. Hal itu dikarenakan tidak adanya pelatihan khusus dalam penggunaan alat sehingga masih terjadinya kecelakaan kerja yang diakibatkan oleh metode kerja yang salah dalam pelaksanaan suatu pekerjaan.

6. Penerapan sistem manajemen $\mathrm{K} 3$ dalam penanganan kecelakaan kerja terangkum dalam Plan, Do, Check and Action (PDCA) dimana Plan dan Do dalam hal ini dapat mengalami pembaharuan apabila ditemukan indikasi kecelakaan kerja (Check) untuk 
selanjutnya dilakukan tindakan penanggulangannya (Action) dan upaya pencegahan selanjutnya (Plan II). 